\title{
HUBUNGAN TINEA PEDIS DENGAN LAMANYA BEKERJA SEBAGAI NELAYAN DI PULAU PANGGANG KEPULAUAN SERIBU JAKARTA UTARA
}

\author{
Fadlilla Muhtadin $^{(1)}$, Imas Latifah $^{(2)}$ \\ Program studi DIII- Analis Kesehatan Universitas MH Thamrin \\ aakmht@yahoo.com
}

\begin{abstract}
ABSTRAK
Tinea Pedis merupakan suatu infeksi kulit yang disebabkan oleh jamur golongan dermatofita, yakni jamur yang menginfeksi permukaan tubuh dan mengandung zat tanduk (keratin) yang terlokalisasi pada startum komeum kulit sela-sela jari kaki. Kejadian infeksi Tinea Pedis ini dapat dipengaruhi oleh berbagai faktor diantaranya adalah faktor lingkungan kerja dan perilaku. Nelayan adalah salah satu profesi pekerja, dimana dalam melakukan pekerjaannya selalu kontak dengan air yang menyebabkan kaki menjadi lembab dan menjadikan kaki tempat yang menguntungkan untuk pertumbuhan jamur Tinea pedis. Tujuan dari penelitian ini adalah untuk mengetahui gambaran infeksi Tinea pedis pada kerokan kulit sela-sela jari kaki nelayan dan hubungannya dengan lamanya bekerja sebagai nelayan di Pulau Panggang Kepulauan Seribu Jakarta Utara.Penelitian ini dilakukan menggunakan desain studi cross sectional dengan mengambil sampel 60 nelayan di Pulau Panggang Kepulauan Seribu Jakarta Utara. Bahan pemeriksaan yang digunakan berupa kerokan kulit sela-sela jari kaki yang diambil menggunakan scalpel, yang kemudian dilakukan pemeriksaan langsung secara mikroskopik. Dari hasil pemeriksaan terhadap 60 sampel kerokan kulit sela-sela jari kaki nelayan berdasarkan lamanya bekerja sebagai nelayan selama $>3$ tahun terdapat 19,51\% mengalami Tinea pedis, dan nelayan yang bekerja 3 tahun tidak ada yang mengalami infeksi Tinea Pedis $(0 \%)$, dan berdasarkan perhitungan statistik dapat diketahui adanya hubungan bermakna antara keberadaan jamur Tinea pedis pada kerokan kulit sela-sela jari kaki dengan lamanya berprofesi sebagai nelayan. Kejadian infeksi Tinea Pedis pada nelayan di Pulau Panggang Kepulauan Seribu ini juga dipengaruhi oleh durasi bekerja dalam sehari dan kebiasaan menggunakan sepatu. Kesimpulan dari penelitian ini adalah semakin lama bekerja sebagai nelayan semakin besar risiko mengalami Tinea Pedis pada Nelayan di Pulau Panggang Kepulauan Seribu Jakarta Utara.
\end{abstract}

Kata kunci: Tinea Pedis, Nelayan, Lama Bekerja.

\section{PENDAHULUAN}

Indonesia merupakan salah satu negara beriklim tropis yang memiliki suhu dan kelembaban tinggi, merupakan suasana yang baik bagi pertumbuhan jamur, sehingga jamur dapat ditemukan hampir di semua tempat (Hidayati et al,2009).

Lingkungan kerja merupakan tempat yang potensial mempengaruhi kesehatan pekerja. Faktor-faktor yang dapat mempengaruhi kesehatan pekerja antara lain faktor fisik, faktor kimia, dan faktor biologis. Lingkungan kerja ataupun jenis pekerjaan dapat menyebabkan penyakit akibat kerja (Kurniawati, 2006).

Dermatofitosis ialah penyakit yang disebabkan oleh kolonisasi jamur dermatofit yang menyerang jaringan yang mengandung keratin seperti stratum korneum kulit, rambut dan kuku pada manusia.Terdapat tiga genus penyebab dermatofitosis, yaitu Microsporum, Trichophyton, dan Epidermophyton (Wolff and Johnson, 2012).

Prevalensi penyakit dermatofitosis di Asia mencapai 35,6\% (Kumar et al, 2011). Di Indonesia sendiri pada tahun 2000-2004 prevalensinya mengalami peningkatan 14,4\% (Hidayati, 2009). Dari keseluruhan insidensi berhubungan pekerja dengan pekerjaan, sehingga sering disebut dermatofitosis akibat kerja antara lain Tinea pedis (Kumar, et al 2011).

Tinea pedis merupakan salah satu infeksi kulit pada sela jari kaki dan telapak kaki yang disebabkan oleh Trichophyton rubrum (Viegas et al, 2013; Wolff dan Johnson, 2012).Prevalensi Tinea pedisberdasarkan data statistik dari beberapa rumah sakit pendidikan di Indonesia seperti RS. Dr. Soetomo, RSCM, RS. Dr. Hasan 
Sadikin, RS. Dr. Sardjito didapatkan hasil Relative 16\% (Adiguna, 2004). Di National Skin Care Singapura pada tahun 1999-2000, presentase Tinea pedis mencapai 27,3\% (Tan, 2005). Di Chumitshu Chuo Hospital Tokyo Jepang, presentasi Tine pedis mencapai 64,2\% (Takahashi, 2002). Berdasarkan data staistik Poliklinik kulit dan kelamin RSUD Dr. Moerwadi Surakarta pada bulan Januari 2011 jumlah kunjungan kasus dermatofitosis hampir tidak ditemukan, karena penyakit ini tidak lagi menjadi jangkauan fasilitas kesehatan tingkat tiga atau empat seperti RSUD Dr. Moewardi (Diklat RSUD Dr. Moewardi, 2015).Hasil wawancara dengan dinas kesehatan kota Surakarta, 10 besar penyakit kulit yang ada di seluruh puskesmas Surakarta menunjukan bahwa Tinea pedis termasuk di dalamnya (Dinkes, 2015). Banyaknya kasus Tinea pedis tersebut antara lainkebiasaan pemakaian sepatu tertutup dalam aktivitas atau pekerjaan sehari-hari (Ervianti et al, 2002).

Berdasarkan hasil penelitian dari Kurniawati (2006), Tinea pedis pada pemungut sampah di tempat pembuangan akhir Jatibarang Semarang dengan 56 orang pemulung ditemukan 26 (46,43\%) positif Tinea pedis. Sedangkan pada penelitian lain tentang angka kejadian Tinea pedis juga perna dilakukan pada siswa PK gelombang 1 tahap II TNI AD di pusdikes kodilat TNI AD Jakarta Timur penelitian menemukan kejadian Tinea pedis sebanyak 10\% (Saepuddin, M: 2013). Menurut Soendoro, T 2007 di Wakatobi dan kota Bau-Bau Prevalensi dermatitis tertinggi (>10\%).

Dalam penelitian ini peneliti memilih pekerjaan dengan lingkungan kerja yang memiliki faktor risiko terjadinya Tinea pedis.Nelayan adalah salah satu contoh okupasi yang kesehariannya bekerja di air menggunakan sepatu tertutup dengan waktu yang cukup lama dan sering.Ruang lingkup kerja mereka juga seputar daerah, panas dan lembab.Hal-hal tersebut merupakan beberapa faktor yang memudahkan timbulnya infeksi jamur pada kaki atau Tinea pedis (Kurniawati, 2006).

Untuk melihat apakah ada infeksi jamur maka perlu dibuat preparat langsung dari kerokan kulit.Sediaan diteteskan $\mathrm{KOH} 10 \%$ dengan maksud malarutkan atau melisiskan keratin kulit, dengan demikian maka tinggal kelompok hifa.Adanya elemen jamur tampak berupa benang-benang bersifat kontur ganda.Selain itu tampak juga bintik spora berupa bola-bola kecil sebesar 1-3 $\mu \mathrm{m}$. Dengan pemeriksaan langsung diagnosis suatu dermatofitosis sudah dapat ditegakkan (Siregar, 2004).

Kerokan kulit atau serpihan zat keratin pada selofan dapat digunakan untuk melihat artrospora dan atau hifa sejati.Hasil kerokan kulit atau keratin yang menempel pada selofan diletakan diatas kaca obyek lalu ditetesi $\mathrm{KOH} 10 \%$ dan ditutup dengan kaca penutup. Pemberian KOH dimaksudkan untuk melisiskan sel-sel epitel sehingga mempermudah dalam mengidentifikasi elemen jamur yang akan dicari (Halsted,J.A.,Halsted,C.H., 1981).Hifa sejati terlihat ramping lurus atau bercabang dengan terdapat ruas-ruas.Sedangkan artrospora terbentuk dari hifa-hifa pada kulit yang terlihat sebagai spora-spora yang tersusun padat memanjang. Hasil pemeriksaan langsung yang positif menegaskan diagnosa, dan pemeriksaan kultur diperlukan untuk identifikasi jamur pathogen spesifik penyebab infeksi. Sedangkan pemeriksaan $\mathrm{KOH}$ yang negatif sebaiknya dilakukan pemeriksaan berulang beberapa waktu kemudian dari gejala klinis yang dicurigai (Gandahusada, S., lllahude, HD. dan Pribadi, W 1998).

Pemeriksaan dengan $\mathrm{KOH}$, bila penyebab kelainannya adalah oleh Candida, pada kerokan kulit akan terlihat sel ragi (blastospora) berkelompok, kadang-kadang sulit dibedakan dari hifa sejati dermatofita sehingga diperlukan pemeriksaan biakan untuk memastikan koloni dermatofita sehingga diperlukan pemeriksaan biakan untuk 
memastikan koloni dermatofita dengan koloni jamur lain (Budimulja,u., 1983).Media lain selain media SDA yang dapat digunakan untuk pembiakan dermatofita adalah DTM (Dermatophyte Test Media). Bila tumbuh dermatofita maka akan terjadi perubahan warna pada medium tersebut dari kuning menjadi merah. Hal ini karenakan terjadi perubahan suasana pH medium dari asam menjadi basa (Budimulja, U., 1980) (Halsted,J.A., Halsted,C.H., 1981).

Slide Culture adalah satu tehnik identifikasi spesies jamur dengan menggunakan kaca ubyek sebagai dasar biakannya. Kaca obyek tersebut diberi potongan media pembenihan misalnya Agar Sabouraud Dektrosa (SDA), kemudian koloni jamur di inokulasi pada media tersebut. Jamur yang tumbuh akan menempel pada permukaan kaca obyek dan kaca penutup sehingga sporulasi jamur akan tersusun dengan baik sehingga penetapan spesies akan mudah dilakukan dengan melihat sporulasi yang khas (Mulyati, 2015).

Setelah dilakukan observasi oleh peneliti di Pulau Panggang Kepulauan Seribu Jakarta Utara, melihat kondisi masyarakat dengan lingkungan yang hampir seluruhnya adalah perairan dan mata pencahariannya adalah sebagai nelayan, kemungkinan terpapar jamur akan semakin tinggi. Oleh karena itu peneliti tertarik untuk melakukan penelitian terhadap Tinea pedis pada kerokan kulit sela-sela jari kaki nelayan di Pulau Panggang Kepulauan Seribu Jakarta Utara. Tujuan penelitian ini adalah untuk mengetahui gambaran infeksi Tinea Pedis pada nelayan dan hubungannya dengan lamanya bekerja nelayan di Pulau Panggang Kepulauan Seribu Jakarta Utara.

\section{METODE}

Metode penelitian yang digunakan dalam penelitian ini adalah deskriptif analitik dengan desain penelitian cross-sectional. Populasipenelitian adalah seluruh nelayan di Pulau Panggang Kepulauan Seribu Jakarta Utara dengan sampel sebanyak 60 yang dihitung berdasarkan Lemeshow,1997. Bahan pemeriksaan yang digunakan adalah kerokan kulit sela-sela jari kaki nelayan di Pulau Panggang Kepulauan Seribu Jakarta Utara yang bersedia diambil sebagai sampel. Teknik pengumpulan data menggunakan kuisioner dan pemeriksaan mikroskipos secara langgsung dengan menggunakan $\mathrm{KOH}$ 10\% untuk melisiskan sel-sel epitel sehingga elmen jamur yang berupa hifa sejati dan atau artospora dapat kelihatan dengan jelas pada pembesaran 100-400 kali.

Analisa data menggunakan univariat (untuk mengetahui gambaran persentase Tinea Pedis) dan bivariat(digunakan untuk mengetahui hubungan antara variabel Tinea Pedis dengan lamanya bekerja sebagai nelayan). Data dianalisis dengan menggunakan uji chi-square.

\section{HASIL}

Analisis univariat Menunjukan bahwa dari 60 sampel terdapat sebanyak 13,33\% (8 orang) positif mengalami Tinea Pedis berdasarkan ditemukannya elem jamur pada kerokan kulit dan sebanyak 86,66\% (52 orang) negatif (tidak ditemukan elemen jamur pada kerokan kulit). Penelitian ini sejalan dengan hasil penelitian yang dilakukan oleh Umah, (2016) tentang angka kejadian Tinea pedis yang pernah juga dilakukan pada Nelayan di Kampung Muara Mati Kecamatan Muaragembong Bekasi penelitian menemukan kejadian Tinea Pedis sebanyak 9,09\%.Rahma (2015), menemukan angka kejadian Tinea pedis 6,67 \% pada Pedagang Ikan di Pasar Kramat Jati Jakarta Timur. Analisis bivariat Hubungan Tinea Pedis dengan lamanya bekerja sebagai nelayan pada Nelayan di Pulau Panggang Kepulauan Seribu Jakarta Utara, berdasarkan lamanya bekerja sebagai 
nelayan selama $<3$ tahun sebesar $0 \%$ mengalami Tinea pedis, dan nelayan yang bekerja $>3$ tahun terdapat 19,51\% mengalami Tinea pedis. Dari hasil perhitungan statistik Chi-square diketahui ada hubungan bermakna antara Tinea pedis dengan lamanya bekerja sebagai nelayan $(\mathrm{P}<0,05)($ Tabel 1$)$.

Tabel 1

Hubungan Tinea Pedis dengan Lama Bekerja sebagai Nelayan di Pulau Panggang Kepulauan Seribu Jakarta Utara

\begin{tabular}{lcccc}
\hline \multicolumn{1}{c}{ Variable yang diamati } & $+\%$ & $-\%$ & Jumlah & P.value \\
\hline Profesi nelayan & & & & \\
<3 Tahun & $0(0 \%)$ & $19(80,48 \%)$ & 19 & $\mathrm{X}^{2}=0,039$ \\
$>3$ Tahun & $8(19,51 \%)$ & $33(100 \%)$ & 41 & $<0,05$ \\
& & & & \\
\hline
\end{tabular}

\section{PEMBAHASAN}

Berdarakan hasil diatas, hal ini membuktikan bahwa memang lamanya bekerja pada nelayan merupakan faktor predisposisi yang dapat memicu terjadinya infeksi Tinea Pedis sebagaimana menurut Kurniawati (2006), nelayan adalah salah satu contoh okupasi yang kesehariannya bekerja di air menggunakan sepatu tertutup dengan waktu yang cukup lama dan sering. Ruang lingkup kerja mereka juga seputar daerah, panas dan lembab.Hal-hal tersebut merupakan beberapa faktor yang memudahkan timbulnya infeksi jamur pada kaki atau Tinea pedis.

Lingkungan tempat kerja merupakan tempat yang potensial mempengaruhi kesehatan para pekerja yang berkaitan dengan faktor fisik, faktor kimia, dan faktor biologis.Lingkungan kerja ataupun jenis pekerjaan dapat menyebabkan penyakit akibat kerja.Pada umumnya jamur tumbuh dengan baik di tempat yang lembab dan jamur juga dapat menyesuaikan diri dengan lingkungannya sehingga kalau hal ini terus berlangsung lama maka para nelayan akan semakin berpotensi untuk mengalami infeksi jamur khususnya Tinea Pedis. Berdasarka variable durasi waktu bekerja nelayan yang bekerja selama $<6$ jam / hari terdapat $0 \%$ tidak mengalami Tinea pedis, dan nelayan yang bekerja $>6$ jam / hari sebanyak 8 orang atau sebesar $25 \%$ mengalami Tinea pedis. Dari hasil perhitungan statistik Chi-square dinyatakan ada hubungan bermakna antara Tinea pedis dengan durasi bekerja dalam sehari $(\mathrm{P}<0,05)$ (Tabel 2).

Tabel 2

Hubungan Tinea Pedis dengan Durasi Bekerja Nelayan di Pulau Panggang Kepulauan Seribu Jakarta Utara

\begin{tabular}{ccccc}
\hline Variable yang diamati & $\mathbf{+ \%}$ & $-\boldsymbol{\%}$ & Jumlah & Value \\
\hline Waktu kerja & & & & \\
< 6 Jam & $0(0 \%)$ & $28(100 \%)$ & 28 & $\mathrm{X}^{2}=0,004$ \\
> 6 Jam & $8(25 \%)$ & $24(75 \%)$ & 32 & $<0,05$ \\
\hline
\end{tabular}

Dari hasil di atas dapat menunjukan bahwa jam kerja yang lebih lama menunjukan hasil yang positif Tinea pedis lebih banyak di bandingkan dengan jam kerja yang lebih sedikit. Semakin lama jam kerja, resiko terjadinya tinea pedis pada nelayan semakin tinggi. Hal ini sesuai pendapat Febriyani (2015) tentang semakin lama kontak dengan pekerjaanya maka peradangan atau iritasi kulit dapat terjadi sehingga menimbulkan kelainan kulit. Kondisi ini akan semakin diperparah apabila para nelayan tersebut kurang memperhatikan kebersihan dirinya masing-masing terutama tidak selalu mencuci kaki setelah mereka selesai bekerja. 
Berdasarkan pemeriksaan terhadap variable yang diamati, ternyata nelayan yang bekerja menggunakan sepatu karet 25,92 \% mengalami Tinea pedis sedangkan yang tidak menggunakan sepatu karet hanya 3,03 $\%$.Dari hasil perhitungan statistik Chi-square maka dapat diketahui adanya hubungan bermakna antara Tinea Pedis dengan pemakaian sepatu karet $(\mathrm{P}<0,05)($ Tabel 3)

Tabel 3

Hubungan Tinea Pedis dengan Pemakaian Sepatu Karet Pada Nelayan di Pulau Panggang Kepulauan Seribu Jakarta Utara

\begin{tabular}{lcccc}
\hline Variable yang diamati & $\mathbf{+ \%}$ & $\mathbf{- \%}$ & Jumlah & Value \\
\hline Memakai sepatu & $7(25,92 \%)$ & $20(74,07 \%)$ & 27 & $X^{2}=0,009$ \\
Ya & $1(3,03 \%)$ & $32(96,96 \%)$ & 33 & $<0,05$ \\
Tidak &
\end{tabular}

Kondisi ini juga dihubungkan dengan kebiasaan nelayan yang menggunakan sepatu yang berbahan dasar karet. Sepatu berbahan karet tidak menyerap keringat tentunya hal itu akan membuat kaki memproduksi keringat yang lebih banyak sehingga tingkat kelembaban kaki menjadi tinggi, ditambah dengan aktivitas nelayan yang memang keseharianya selalu berhubungan dengan air. Lingkungan berpengaruh besar untuk timbulnya penyakit, seperti pekerjaan dengan lingkungan basah, tempat-tempat lembab atau panas, pemakaian alat-alat yang salah (Siregar, 2004), hal ini juga sesuai yang di lakukan Soekandar (2004), dan Kurniawati (2006), yang sama-sama menyatakan bahwa pemakaian sepatu tertutup untuk waktu yang lama, merupakan faktor risiko yang menyebabkan terjadinya Tinea pedis.

Banyaknya kasus Tinea pedis tersebut antara laindapat dipengaruhi oleh kebiasaan pemakaian sepatu tertutup dalam aktivitas atau pekerjaan sehari-hari (Ervianti et al, 2002). Tinea pedis sering menyerang orang dewasa usia 20-50 tahun yangbekerja di tempat basah seperti tukang cuci, nelayan, pedagang ikan, petani atau orang yang tiap hari memakai sepatu tertutup (Soekandar, 2001).

Bertambahnya kelembaban karena keringat, pecahnya kulit karena mekanis, dan paparan terhadap jamur merupakan faktor predisposisi yang menyebabkan Tinea pedis (Kumar et al, 2011).

\section{KESIMPULAN DAN SARAN}

Kesimpulan penelitian ini yaitu Semakin lama bekerja sebagai nelayan semakin besar risiko mengalami Tinea Pedis pada Nelayan di Pulau Panggang Kepulauan Seribu Jakarta Utara.Kejadian Tinea Pedis juga dipengaruhi oleh durasi bekerja dalam sehari dan pemakaian sepatu karet selama bekerja pada Nelayan di Pulau Panggang Kepulauan Seribu Jakarta Utara. Saran Penelitian selanjutnya sebaiknya dilengkapi dengan pemeriksaan biakan untuk mengetahuii spesies apa yang menginfeksi Tibea pedis pada nelayan dan Meneliti variable-variabel lain seperti faktor lingkungan, Personal hygine dan sanitasi, dan keluhan.

\section{DAFTAR PUSTAKA}

1. Adiguna, M.S., Epidemiologi Dermatomikosis Superfisialis, Dalam: Budimulja, U. Dermatomikosis Superfisialis. Jakarta: Balai Penerbit FKUI,2004.

2. Budimulja, U., Penyelidikan Dermatophytosis Di Rumah Sakit Cipto Mangunkusumo, Tesis Doktor, FKUI, Jakarta,1980. 
3. Budimulja, U., Ilmu Penyakit Kulit dan Kelamin Edisi 5. Jakarta: FKUI, 2007.

4. Dewi, R.M., Tinea Pedis Pada Pedagang Tahu. KTI.DIII Jurusan Analis Kesehatan, Poltekkes Kemenkes Jakarta III 2008.

5. Diklat, Dinas Kesehatan Kota Surakarta, (personal communication), 8 Oktober 2015.

6. Diklat, RSUD Dr. Moewardi, (personal communication), 8 Oktober 2015.

7. Emmy Sm Dailli Sjamsoe, dkk., Penyakit Kulit Yang Umum di Indonesia, PT Medica Multimedia Indonesia. 2005.

8. Ervianti, E., Martidiharjo, S., Murtiastutik D., Etiologi dan Pathogenesis Dermatomikosis Superficialis. RSU Dr. Soetomo/ FK UNAIR. Dalam Simposium Penatalaksanaan Dermatomikosis Superficialis,2002.

9. Gandahusada, S., Illahude, HD. dan Pribadi, W.,Buku Ajar Parasitologi Kedokteran,edisi ketiga. Fakultas Kedokteran Universitas Indonesia, Jakarta,1998.

10. Halsted, James,A. Halsted, Charles,H., The Laboratory in Clinical Medicine Interpretation and Aplication, second edition, W.B. Saunders Company, Philadelphia, 1981.

11. Harahap, Mawarli., Ilmu Penyakit Kulit, Hipokrates, Jakarta, 2000.

12. Hidayati, A.N., Suroso, S., Hinda, D., Sandra, E.,.Superficial Mycosis in Mycology Division Out Patient Clinic of Dermatovenereology, Vol 21Fakultas Kedokteran Universitas Airlangga, 2009.

13. Jawetz, Melnick., dan Adelberg., Mikrobiologi Kedokteran Edisi 25., EGC. Jakarta. 2010.

14. Kumar, V., Tilak, R., Prakash, P., Nigam, C., Tinea Pedis- an Update.Asian Journal of Medical Sciences.Vol 2: 134-8,2011.

15. Kumiati, C, R., Etiopatogenesis Dermatofitosis. Berkala Ilmu Kesehatan Kulit dan Kelamin.vol.20 No.3. Surabaya. 2008

16. Kurniawati, R.D., Faktor-Faktor yang Berhubungan Dengan Kejadian Tinea pedis Pada Pemulung di TPA Jatibarang Semarang. Thesis. Universitas Diponegoro, 2006.

17. Mulyati, Buku Penuntun Praktikum Mikologi Jurusan Analis Kesehatan. Jakarta, 2015.

18. Siregar, R.S., Penyakit Jamur Kulit Edisi 1 Jakarta: EGC, 2005, pp. 17-21.

19. Soekandar, T.M., Dermatomikosis Superficilis Pedoman Untuk Dokter dan Mahasiswa Kedokteran. Jakarta: FKUI, 2001, pp.8-10.

20. Sukandar, E.Y., Andrjati, R., Sigit, J.I., Andyana, I.K., Setiadi, A.P.,.Iso Farmakoterapi. Edisi 1 Jakarta: PT.ISFI, 2008, pp. 121-6.

21. Takahashi,.Dermatophyte Flora at the Dermatology Clinic of Kimitsu Chuo Hospital from 1994 through 1999.Nippon Ishinkin Gakkai Zasshi.Vol 43 (1),2002.

22. Tan, H.H.,Superficial Fungal Infections seen at National Skin Centre Singapore. Journal Medical of Mycology,2005Vol 46: 77-8

23. Triono Soendoro, Prevalensi Dermatitis Kontak Pada Nelayan Di Wakatobi, Wakatobi, 2007

24. Umah, R.R., Pemeriksaan Tinea Pedis Pada Kerokan Kulit Kaki Nelayan Di Kampung Muara Mati Kecamatan Muaragembong Bekasi. Jakarta, 2016. 
25. Viegas, C., Sabino, R., Parada, H., Brandao, J., Carolino, E.,Diagnosis of Tinea pedis and Onychomycosis in Patients from Carlo CJ, Bowe MC. Tinea pedis Athlete's foot. Saude and Tekhnology.ISSN: 1646-9704, 2013.

26. Wollf, K., dan Johnson, R.A.,Fitzpatrick Color Atlas and Synopsis of Clinical Dermatology Edisi 6. ISBN: 978-0-07-163342-0, 2012. 